\title{
Precursor-Receptor Interactions in the Twin Arginine Protein Transport Pathway Probed with a New Receptor Complex Preparation
}

\author{
Marta Wojnowska, ${ }^{\dagger, \S}$ Joseph Gault, ${ }^{\ddagger}$ Shee Chien Yong, ${ }^{\dagger, \|}$ Carol V. Robinson, ${ }^{\ddagger}$ and Ben C. Berks ${ }^{*}, \dagger$ \\ ${ }^{\dagger}$ Department of Biochemistry, University of Oxford, South Parks Road, Oxford OX1 3QU, United Kingdom \\ ${ }^{\ddagger}$ Physical and Theoretical Chemistry Laboratory, Department of Chemistry, University of Oxford, South Parks Road, Oxford OX1 \\ 3QZ, United Kingdom
}

Supporting Information

\begin{abstract}
The twin arginine translocation (Tat) system moves folded proteins across the cytoplasmic membrane of bacteria and the thylakoid membrane of plant chloroplasts. Signal peptide-bearing substrates of the Tat pathway (precursor proteins) are recognized at the membrane by the TatBC receptor complex. The only established preparation of the TatBC complex uses the detergent digitonin, rendering it unsuitable for biophysical analysis. Here we show that the detergent glyco-diosgenin (GDN) can be used in place of digitonin to isolate homogeneous TatBC complexes that bind precursor proteins with physiological specificity. We use this new preparation to quantitatively characterize TatBC-precursor interactions in a fully defined

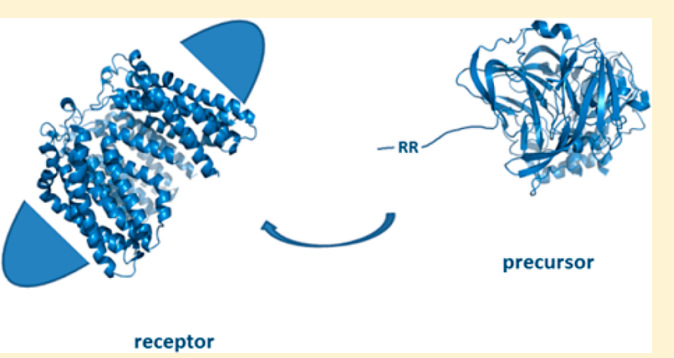
system. Additionally, we show that the GDN-solubilized TatBC complex co-purifies with substantial quantities of phospholipids.
\end{abstract}

$\mathrm{T}^{\mathrm{m}}$ he twin arginine translocation (Tat) system is one of two protein export pathways in the cytoplasmic membrane of prokaryotes. ${ }^{1,2}$ It has been conserved in eukaryotes as a protein uptake pathway in plant chloroplast thylakoids ${ }^{3,4}$ and is also found in some mitochondria. 5 The Tat apparatus transports fully folded proteins. How this is achieved without significant leakage of ions across the membrane is still unclear.

In the bacterium Escherichia coli, and in plant chloroplasts, the Tat system involves the three membrane proteins TatA, TatB, and TatC. Proteins are targeted to the Tat system as precursor proteins possessing signal peptides. These signal peptides bear a distinctive sequence motif containing a pair of consecutive arginine residues. ${ }^{7,8}$ The signal peptides are recognized by a protein complex containing TatB and TatC. ${ }^{9,10}$ The twin arginine-containing motif on the signal peptide is bound at a site on the cytoplasmic face of TatC. ${ }^{1-13}$ Signal peptide binding is thought to induce a structural rearrangement in the TatBC complex $^{14,15}$ leading to the recruitment of multiple TatA protomers from a pool in the membrane to form the active transport site. ${ }^{16-18}$ Following transport, the signal peptide is cleaved from the transported protein and TatA is released from the TatBC complex back into the membrane pool.

The TatBC complex forms the core of the Tat translocation apparatus. It acts both as a receptor for the precursor protein and as the scaffold to which TatA is recruited. Although the structures of the individual TatB and TatC proteins are now known, ${ }^{11,19,20}$ the organization of these proteins within the TatBC complex has not been fully established. ${ }^{4,14,21}$ It is, however, known that the complex contains multiple copies of the constituent TatB and TatC proteins ${ }^{17,22-25}$ and that the two polypeptide types are present at equimolar ratios. ${ }^{14,26}$ Using the detergent digitonin, it is possible to solubilize the TatBC complex in a homogeneous state as judged by blue native polyacrylamide gel electrophoresis (BN-PAGE) ${ }^{9,27,28}$ If detergents other than digitonin are used to solubilize the complex, a range of oligomeric states are detected (e.g., ref 9). It is generally considered that this compositional heterogeneity is a result of fragmentation of the TatBC complex that can be purified in digitonin.

The interactions the TatBC complex makes with Tat precursor proteins have been the subject of extensive investigations by mutagenesis, co-purification, and cross-linking analysis. ${ }^{9,10,12,13,21,29-34}$ Nevertheless, there is only very limited and mainly semiquantitative information about the interaction strength and kinetics of binding, and this information all derives from experiments in complex native membrane systems. ${ }^{29,35-37}$ To expand our knowledge of Tat-precursor interactions, it would be valuable to be able to use biophysical methods to quantitatively characterize the interactions between precursors and the TatBC complex using purified proteins. Such measurements are technically challenging when dealing with large membrane protein complexes. They are made even more problematic in the case of the TatBC complex because the established preparative method uses digitonin as the detergent. Even highly purified solutions of digitonin exhibit progressive clouding over time. This creates a number of issues in biophysical analysis, including baseline drift and instrument clogging. Thus, to apply advanced biophysical methods to the purified TatBC

Received: January 9, 2018

Revised: February 19, 2018

Published: February 20, 2018 
complex, we require a stable, homogeneous preparation of the protein in a detergent other than digitonin. Here we show that the recently synthesized detergent glyco-diosgenin (GDN) ${ }^{38}$ can be used in place of digitonin to isolate homogeneous TatBC complexes with physiological substrate binding specificity. We use this preparation to assess the thermodynamics and kinetics of the interactions between the TatBC complex and precursor proteins.

\section{EXPERIMENTAL DETAILS}

Plasmid Construction. The gene expression plasmids used in this study are listed in Table S1, and the mutagenic primers employed to make new constructs are listed in Table S2. Plasmid pFAT75 $\triangle$ ASH was constructed by making an in-frame deletion of tatA in pUNITAT2 $\mathrm{Cys}^{-39}$ and then using polymerase chain reaction with primers pFAT75DASTREPhisFor and pFAT75DASTREPhisRev to insert a strep II tag coding region between tatC and the $\mathrm{His}_{6}$ tag-coding region. Plasmid pGEX-CueOGS3His was generated as follows. The cueO gene was amplified without a stop codon from plasmid pSC-22 ${ }^{29}$ using primers SC037 and CY002, and the resulting fragment was cloned between the BamHI and XhoI sites of plasmid pGEX-6P-2 (GE Healthcare) to make plasmid pGEX-CueO(nostop). A fragment encoding a (GGGGS) ${ }_{3}$ linker was then amplified from plasmid pPCR-GS3 $^{40}$ using primers CY005 and CY006 and cloned between the XhoI and HindIII sites in pGEX-CueO(nostop). Plasmid pGEX-MdoDHis was constructed by amplifying a $m d o D$-containing BamHI-XhoI fragment from E. coli genomic DNA using primers CY020 and CY021 and cloning into the same sites in pGEX-6P-2 (GE Healthcare). All KK for RR substituted variants were constructed by QuikChange mutagenesis (Agilent Genomics).

Protein Production and Purification. Proteins were routinely overproduced in $\triangle$ tatABCD $\Delta$ tatE $E$. coli strain $\mathrm{DADE}^{41}$ containing the appropriate expression plasmid and cultured on LB medium ${ }^{42}$ supplemented with $0.4 \%(w / v)$ glycerol and appropriate antibiotics $(100 \mu \mathrm{g} / \mathrm{mL}$ ampicillin, 50 $\mu \mathrm{g} / \mathrm{mL}$ kanamycin, and $25 \mu \mathrm{g} / \mathrm{mL}$ chloramphenicol). pQE60based expression protein vectors were co-transformed with pREP4 ( $\operatorname{Kan}^{\mathrm{R}}$, lacI ${ }^{+}$, Roche); $750 \mathrm{~mL}$ of medium in baffled $2.5 \mathrm{~L}$ flasks was inoculated with $10 \mathrm{~mL}$ of overnight culture and then cultured aerobically at $37{ }^{\circ} \mathrm{C}$. A final isopropyl $\beta$-D-1thiogalactopyranoside (IPTG) concentration of $1 \mathrm{mM}$ was added when the cells reached an $\mathrm{OD}_{600}$ of $0.6-0.8$, and the culture was continued for a further $4 \mathrm{~h}$. After being harvested by centrifugation, cells were resuspended in $20 \mathrm{mM}$ MOPS-NaOH, $200 \mathrm{mM} \mathrm{NaCl}$, and $1 \mathrm{mM}$ EDTA ( $\mathrm{pH} \mathrm{8}$ ) and lysed by being passed through a TS series $1.1 \mathrm{~kW}$ cell disruptor (Constant Systems) at $30 \mathrm{~K}$ psi.

For purification of TatBC- $\mathrm{His}_{6}$ complexes, a membrane fraction was first isolated by centrifugation of the whole cell lysate for $10 \mathrm{~min}$ at $12000 \mathrm{~g}$ and the resultant supernatant for $1 \mathrm{~h}$ at $150000 \mathrm{~g}$. The recovered membrane pellet was resuspended in 50 $\mathrm{mM}$ Tris- $\mathrm{HCl}, 200 \mathrm{mM} \mathrm{NaCl}$, and $1 \mathrm{mM}$ EDTA (pH 8), and the volume was adjusted to a final protein concentration of $20 \mathrm{mg} /$ $\mathrm{mL}$ based on Dc Protein Assay (Bio-Rad) measurements. An equal volume of a $2 \%(\mathrm{w} / \mathrm{v}) \mathrm{GDN}$ detergent (Anatrace) solution was added, and the membranes were allowed to solubilize for 16 $\mathrm{h}$ at $4{ }^{\circ} \mathrm{C}$ while being gently agitated. Unsolubilized material was pelleted by centrifugation for $40 \mathrm{~min}$ at $150000 \mathrm{~g}$. The supernatant was supplemented with $12 \mathrm{mM}$ imidazole, mixed with $1 \mathrm{~mL}$ per $1 \mathrm{~L}$ culture of cOmplete His-tag purification resin (Roche) pre-equilibrated in resuspension buffer, and incubated while being gently agitated for $3 \mathrm{~h}$ at $4{ }^{\circ} \mathrm{C}$. The resin was packed into a gravity flow column and washed with 10 column volumes (CV) of column buffer containing $20 \mathrm{mM}$ MOPS-NaOH, 200 $\mathrm{mM} \mathrm{NaCl}, 1 \mathrm{mM}$ EDTA, and $0.01 \%(\mathrm{w} / \mathrm{v}) \mathrm{GDN}(\mathrm{pH} 8)$, and supplemented with $12 \mathrm{mM}$ imidazole. The column was then eluted over $15 \mathrm{CV}$ with a linear 12 to $100 \mathrm{mM}$ imidazole gradient in column buffer. Fractions containing the protein of interest were pooled, concentrated by ultrafiltration in a $100 \mathrm{kDa}$ molecular weight cutoff centrifugal concentrator (Millipore), and applied to a Superose 6 Increase size-exclusion column (GE Healthcare), which had been pre-equilibrated in column buffer. Fractions of interest were pooled and concentrated with a 100 $\mathrm{kDa}$ molecular weight cutoff centrifugal concentrator (Millipore) or, in the case of the TatBC-His 6 preparation for ITC experiments, with a $150 \mathrm{kDa}$ molecular weight cutoff centrifugal concentrator (Pierce). For the TatBC-strepII-His ${ }_{6}$ complex preparation, the material eluted from the nickel resin was loaded onto a $5 \mathrm{~mL}$ Strep-tactin Superflow Plus column (Qiagen), washed with $10 \mathrm{CVs}$ Column Buffer and finally eluted with 2.5 $\mathrm{mM}$ desthiobiotin in Column Buffer. The complex was further purified by size-exclusion chromatography as for the other TatBC complexes.

To purify the HiPIP-His ${ }_{6}$ precursor, whole cell lysates were centrifuged for $30 \mathrm{~min}$ at $30000 \mathrm{~g}$. The resulting supernatant was incubated for $1 \mathrm{~h}$ at room temperature with $1 \mathrm{~mL}$ per $1 \mathrm{~L}$ culture of cOmplete His-tag purification resin that had been preequilibrated in detergent-free column buffer (DFCB) containing $15 \mathrm{mM}$ imidazole. The resin was poured into a gravity flow column, washed with 15 volumes of DFCB containing $15 \mathrm{mM}$ imidazole, and then eluted with 5 volumes of DFCB containing $150 \mathrm{mM}$ imidazole. The eluate was concentrated using a $3 \mathrm{kDa}$ molecular weight cutoff concentrator (Millipore) and applied to a Superdex 75 size-exclusion column (GE Healthcare) that had been pre-equilibrated in DFCB. Selected fractions were pooled and concentrated using a $3 \mathrm{kDa}$ cutoff centrifugal concentrator (Millipore).

C-Terminal fusions of the Tat precursor protein $\mathrm{CueO}$ or MdoD with glutathione $S$-transferase (GST) were overproduced in E. coli C43 $\Delta$ Tat (DE3) cells. ${ }^{28}$ The cells were cultured aerobically in Terrific Broth ${ }^{43}$ at $37{ }^{\circ} \mathrm{C}$ until the $\mathrm{OD}_{600}$ reached 0.6 , whereupon IPTG was added to a final concentration of 0.5 $\mathrm{mM}$ and growth was allowed to continue overnight at $25^{\circ} \mathrm{C}$. The precursor proteins were then purified as previously described ${ }^{29}$ with the exceptions that all buffers were adjusted to $\mathrm{pH} 8$ and contained $1 \mathrm{mM}$ EDTA, and that after the GSTrap column step the fusion proteins were mixed with GST-3C protease and dialyzed overnight at $4{ }^{\circ} \mathrm{C}$ against $20 \mathrm{mM}$ MOPS- $\mathrm{NaOH}, 200$ $\mathrm{mM} \mathrm{NaCl}, 1$ mM EDTA ( $\mathrm{pH} 8$ ) buffer.

Purified proteins were flash-frozen in liquid nitrogen and stored at $-80{ }^{\circ} \mathrm{C}$. Except where specified below, protein concentrations were determined spectrophotometrically using $\varepsilon_{280}$ values calculated using ProtParam. ${ }^{44}$ The molecular masses of all purified precursor proteins were verified by electrospray mass spectrometry.

Protein Electrophoresis. Blue native PAGE used a 4 to $16 \%$ polyacrylamide gradient NativePAGE Novex Bis-Tris gels (Life Technologies). Samples were amended with a final glycerol concentration of $10 \%$ before loading. The dye-containing running buffer was exchanged for dye-free buffer when the dye front reached the middle of the gel. Sodium dodecyl sulfatepolyacrylamide gel electrophoresis (SDS-PAGE) used the buffer system of Laemmli. ${ }^{45}$ For both electrophoresis methods, 
protein bands were visualized by Coomassie R-250 Brilliant Blue staining.

Phospholipid Analysis. Lipids were extracted from the GDN-solubilized TatBC complex using a modified Bligh and Dyer procedure. ${ }^{46}$ Briefly, an $\approx 10 \mu \mathrm{L}$ aliquot of TatBC complex $(4 \mathrm{mg} / \mathrm{mL}$ ) was diluted to a final volume of $100 \mu \mathrm{L}$, and $375 \mu \mathrm{L}$ of a chloroform/methanol mixture (2:1) was added, followed by $125 \mu \mathrm{L}$ of chloroform and $125 \mu \mathrm{L}$ of $\mathrm{H}_{2} \mathrm{O}$. Samples were vortexed and allowed to phase separate. The bottom (organic) layer was removed. To ensure quantitative lipid extraction, a second extraction step was performed on the remaining aqueous layer by further addition of $125 \mu \mathrm{L}$ of $\mathrm{CHCl}_{3}$. The two organic layers were then pooled and evaporated to dryness before being resuspended in $68 \%$ solution $\mathrm{A}$ [acetonitrile/water (60:40), 10 $\mathrm{mM}$ ammonium formate, and $0.1 \%$ formic acid] and $32 \%$ solution B [isopropanol/acetonitrile (90:10), $10 \mathrm{mM}$ ammonium formate, and $0.1 \%$ formic acid] for analysis by reverse phase liquid chromatography tandem mass spectrometry (RP LCMS). ${ }^{47}$

LC-MS was performed using a Dionex UltiMate 3000 RSLC nano System coupled to an LTQ Orbitrap XL hybrid mass spectrometer (Thermo Fisher Scientific). Mixtures of lipid extract and lipid standard in $32 \%$ solution B were loaded on a C18 trap column (Acclaim PepMap 100, C18, $300 \mu \mathrm{m} \times 5 \mathrm{~mm}$, $100 \AA$, Thermo Fisher Scientific) at a flow rate of $10 \mu \mathrm{L} / \mathrm{min}$, washed for $5 \mathrm{~min}$ in $32 \% \mathrm{~B}$, and then transferred onto a C18 column (Acclaim PepMap 100, C18, $75 \mu \mathrm{m} \times 15 \mathrm{~cm}$, Thermo Fisher Scientific) at a flow rate of $300 \mathrm{~nL} / \mathrm{min}$. After $5 \mathrm{~min}$, solvent B was ramped to $65 \%$ over $1 \mathrm{~min}$ and then to $80 \%$ over 6 min before being held at $80 \%$ for $10 \mathrm{~min}$ and then ramped to $99 \%$ over $6 \mathrm{~min}$ and held for $7 \mathrm{~min}$. The column oven was held at 40 ${ }^{\circ} \mathrm{C}$.

LC-MS/MS was initially performed for lipid identification. After a full MS scan acquired in the Orbitrap mass analyzer (AGC target 5e5, resolution of 60000 at $m / z 400)$, tandem MS was performed in a data-dependent fashion using a top 5 method. Ions were selected, fragmented, and detected in the linear ion trap (AGC target 1e4). The collision-induced dissociation (CID) energy was $38 \% \mathrm{NCE}$, and the activation time was $30 \mathrm{~ms}$. Ions were added to a dynamic-exclusion list after being fragmented twice. The lipid identity was confirmed by manually comparing the MS/MS spectra to those in the LIPIDMAPS database. ${ }^{48}$

For quantitative RP LC-MS, the following lipid standards were purchased from Avanti Polar Lipids (Alabaster, AL): 1lauroyl-2-tridecanoyl-sn-glycero-3-phosphoethanolamine (PE 12:0/13:0) (catalog number LM-1100), 1-lauroyl-2-tridecanoyl-sn-glycero-3-phospho(rac-1-glycerol), ammonium salt (PG 12:0/13:0) (catalog number LM-1200), and $1^{\prime}$-[1,2-di(9Ztetradecenoyl)-sn-glycero-3-phospho]-3'-[1-(9Z-tetradecenoyl)-2-(10Z-pentadecenoyl)-sn-glycero-3-phospho]-sn-glycero, ammonium salt [CL 14:1(3)-15:1] (catalog number LM-1802). Lipid extract from a known quantity of TatBC complex was mixed with various amounts of each internal lipid standard and diluted.

Quantitative lipidomics experiments were performed as described above but without the tandem MS step in an effort to improve peak shape. The resulting total ion chromatograms were smoothed, and extracted ion chromatograms were generated. For PE and PG lipids, and lipid standards, the ${ }^{12} \mathrm{C}$ isotope was used to generate the extracted ion chromatograms for the three most abundant lipids in each class. For CL, the entire isotope envelope for all CL lipids was used. The peak areas for each lipid class were then summed and compared, and ratios between the number of lipid and number of TatC molecules were calculated. The standard deviation was calculated from three technical repeats.

Nickel Affinity Pull-Down Experiments. Membranes from DADE cells expressing untagged TatBC from plasmid pFAT75 $\triangle \mathrm{A}$ were isolated as described in Protein Production and Purification, and the membrane pellets were resuspended in $50 \mathrm{mM}$ Tris- $\mathrm{HCl}$ and $200 \mathrm{mM} \mathrm{NaCl}$ ( $\mathrm{pH} \mathrm{8}$ ) (pulldown buffer) to a final protein concentration of $20 \mathrm{mg} / \mathrm{mL}$. Purified hexahistidine-tagged precursor proteins were exchanged into pulldown buffer using Micro Bio-Spin 6 columns (Bio-Rad).

For experiments investigating TatBC-precursor complex formation in detergent solution membrane samples were solubilized in $1 \%(\mathrm{w} / \mathrm{v}) \mathrm{GDN}$ or digitonin (Calbiochem), as appropriate, for $90 \mathrm{~min}$ at $24^{\circ} \mathrm{C}$, and then unsolubilized material was removed by centrifugation for $40 \mathrm{~min}$ at $100000 \mathrm{~g}$. $20 \mu \mathrm{L}$ of a $60 \mu \mathrm{M}$ stock of precursor protein was then added to $110 \mu \mathrm{L}$ of the resulting detergent-solubilized membrane fraction and incubated for $30 \mathrm{~min}$ at $24{ }^{\circ} \mathrm{C}$ while being gently agitated.

For experiments investigating TatBC-precursor complex formation in membranes, $20 \mu \mathrm{L}$ of the $60 \mu \mathrm{M}$ stock of precursor protein was added to $80 \mu \mathrm{L}$ of resuspended membranes and incubated for $30 \mathrm{~min}$ at $24{ }^{\circ} \mathrm{C}$ while being gently agitated. Each sample was amended with $30 \mu \mathrm{L}$ of a $4.3 \%$ (w/v) GDN solution, incubated for $90 \mathrm{~min}$ at $24{ }^{\circ} \mathrm{C}$, and then centrifuged for $40 \mathrm{~min}$ at $100000 \mathrm{~g}$, retaining the supernatant.

The samples prepared by either method were mixed with 20 $\mu \mathrm{L}$ of NiNTA resin (Qiagen) that had been pre-equilibrated with pulldown buffer containing either $0.01 \%$ GDN or $0.15 \%$ digitonin as appropriate. The mixtures were incubated for 30 min at $24{ }^{\circ} \mathrm{C}$ while being gently agitated. The resin was washed five times with $200 \mu \mathrm{L}$ of the same buffer supplemented with 40 $\mathrm{mM}$ imidazole, and the proteins of interest were eluted in $30 \mu \mathrm{L}$ of the same buffer containing $10 \mathrm{mM}$ EDTA. The final eluants were analyzed by immunoblotting using anti-TatC and anti-TatB antibodies $^{14}$ and visualized with the ECL detection system (GE Healthcare).

Isothermal Titration Calorimetry. Experiments were performed in a MicroCal PEAQ-ITC microcalorimeter (Malvern Instruments) at $25{ }^{\circ} \mathrm{C}$, with a stirring speed of $500 \mathrm{rpm}$ and a power offset of $2 \mu \mathrm{cal} / \mathrm{s}$. TatBC-His ${ }_{6}$ was present in the cell, and synthetic signal peptides or a purified HiPIP precursor was used as the titrant. The sample and titrant were prepared in the same batch of ITC buffer [ $20 \mathrm{mM}$ MOPS-NaOH, $200 \mathrm{mM} \mathrm{NaCl}, 1$ $\mathrm{mM}$ EDTA, and $0.01 \%(\mathrm{w} / \mathrm{v})$ GDN ( $\mathrm{pH} 8)]$ to control for possible artifacts arising from varying buffer compositions. Data analysis was performed using the PEAQ ITC Analysis Software (Malvern Instruments).

The concentration of TatBC- $\mathrm{His}_{6}$ was calculated using an $\varepsilon_{280}$ of $33000 \mathrm{M}^{-1} \mathrm{~cm}^{-1}$. This extinction coefficient was determined using a TatBC- $\mathrm{His}_{6}$ sample for which the histidine tag concentration had been directly established through ITC with $\mathrm{Ni}^{2+}$ as the titrant.

The TorA and TorAKK signal peptides were synthesized by Peptide Protein Research Ltd. and have the sequences ${ }_{10}$ SRRRFLAQLGGLTVAGMLGPSLLTPRR ${ }_{36}$ and ${ }_{10}$ SKKRFLAQLGGLTVAGMLGPSLLTPRR 36 , respectively. These peptides correspond to residues $10-36$ of the native TorA signal peptide and the same peptide with a KK for RR substitution of the Tat motif twin arginine residues, respectively. They are identical to peptides TorA-SP10-36 and TorA-SPKK previously reported. ${ }^{49}$ Peptide concentrations were calculated from the absorbance at $205 \mathrm{~nm}$ using the formula $E^{0.1 \%}(\mathrm{mg} / \mathrm{mL})=31 .{ }^{50}$ These values 

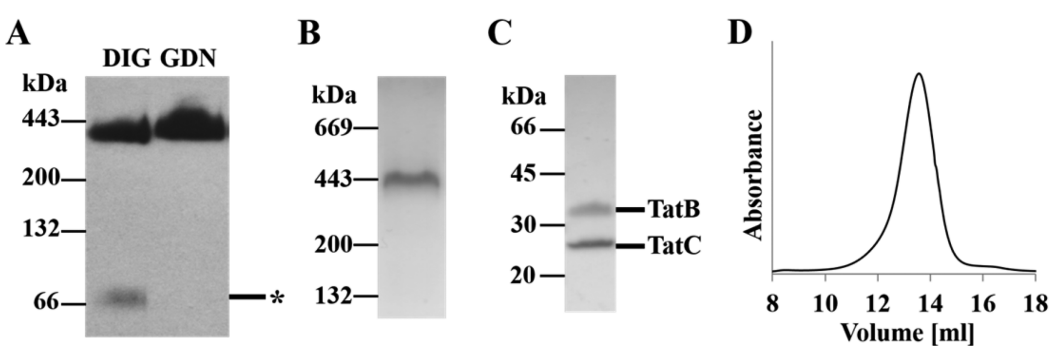

Figure 1. Solubilization and purification of the TatBC complex using the detergent GDN. (A) Solubilization of the TatBC complex from membranes. TatBC-His 6 -containing membranes were solubilized with digitonin (DIG) or GDN, subjected to BN-PAGE, and visualized by immunoblotting with anti-TatC antiserum. The asterisk indicates a fragmentation product of the TatBC complex. Purification of the TatBC complex in GDN. TatBC-His 6 purified in GDN visualized by Coomassie Brilliant Blue staining after (B) BN-PAGE or (C) SDS-PAGE. (D) Size-exclusion elution profile of TatBC$\mathrm{His}_{6}$ in the final purification step.
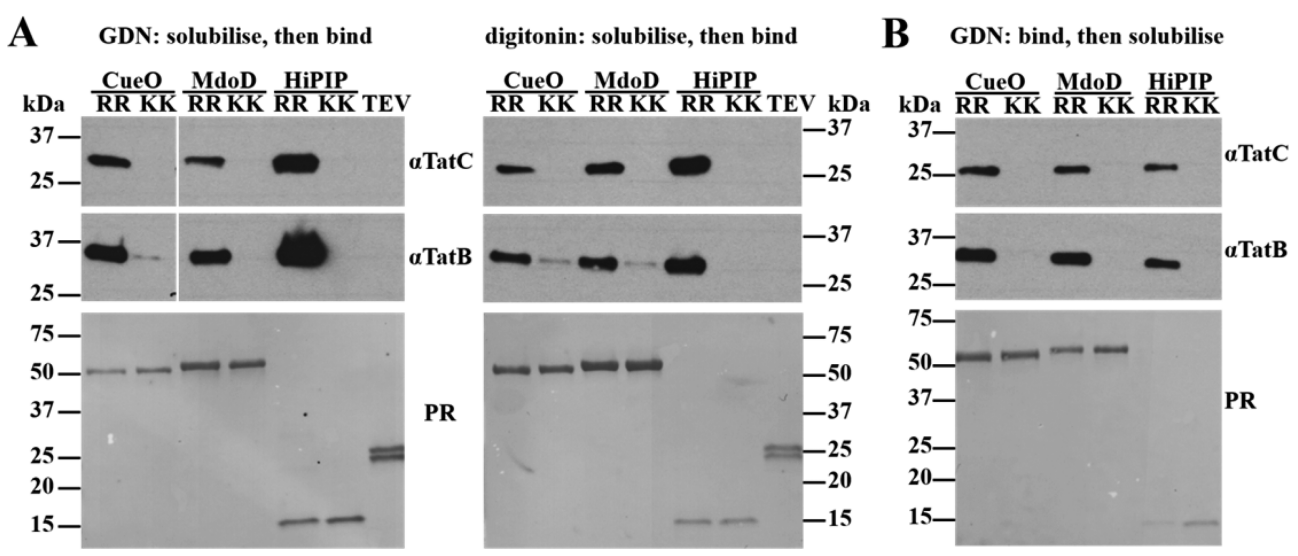

Figure 2. GDN-extracted TatBC complexes retain the ability to bind precursor proteins. (A) GDN-solubilized TatBC complexes bind Tat precursor proteins. Membranes containing untagged TatBC proteins were solubilized in either (left) GDN or (right) digitonin, and the resulting soluble extract was incubated with the indicated precursor proteins. Precursor-containing complexes were then isolated using a hexahistidine tag on the precursor protein. (B) TatBC-precursor interactions are maintained following membrane solubilization with GDN. Membranes containing untagged TatBC were incubated with the indicated precursor proteins and then solubilized with GDN. TatBC-precursor complexes were subsequently isolated from the solubilized extract using the hexahistidine tag on the precursor proteins. In all experiments, the recovered proteins were analyzed by immunoblotting using TatB and TatC antisera (top and center panels). Ponceau Red (PR) staining of the nitrocellulose membranes following transfer (bottom panels) was used to monitor the recovery of the hexahistidine-tagged precursor proteins in the isolation step. RR indicates precursor proteins with the native twin arginine motif in the signal peptide. KK indicates precursor proteins with a twin lysine substitution of the twin arginine motif in the signal peptide. The irrelevant protein hexahistidine-tagged tobacco etch virus protease (TEV) is included as a control for nonspecific binding.

were within $10 \%$ of the peptide concentration for the same sample determined by Fourier transform infrared spectroscopy using a Direct Detect infrared spectrometer (Millipore).

Purified HiPIP precursors used as titrants were exchanged into ITC buffer using Micro Bio-Spin 6 columns (Bio-Rad).

Surface Plasmon Resonance. Experiments were conducted in a Biacore T200 instrument (GE Healthcare) at 25 ${ }^{\circ} \mathrm{C}$ in ITC buffer. The purified analyte proteins were preequilibrated into ITC buffer by buffer exchange using Micro BioSpin 6 columns (Bio-Rad). Polyclonal TatB antibodies ${ }^{14}$ were covalently attached to a CM5 chip (GE Healthcare) by amide coupling. TatBC complexes were immobilized on the chip by flowing a $10 \mu \mathrm{g} / \mathrm{mL}$ solution through one of each pair of flow cells until an immobilization level of approximately 300 response units (RUs) was achieved. The other flow cell in the pair had no TatBC immobilized and was used as the reference. The flow cells were washed with buffer for $60 \mathrm{~s}$. The analyte was then injected continuously for $3 \mathrm{~min}$, and then the flow cells were washed with analyte-free buffer for $10 \mathrm{~min}$. After each analyte run, the TatBC complexes were stripped off the surface by flowing $0.1 \mathrm{M}$ glycine ( $\mathrm{pH} 1.5)$ for $80 \mathrm{~s}$, followed by a buffer wash. The data were analyzed using BIA Evaluation software (GE Healthcare).

\section{RESULTS}

Purification of the $E$. coli TatBC Complex Using GDN. Digitonin is the only detergent known to extract the E. coli TatBC complex in a homogeneous state. However, such digitoninsolubilized TatBC preparations are not suitable for the biophysical analysis of precursor interactions for the reasons outlined in the introductory section. To overcome this problem, we searched for an alternative detergent that would enable the production of a homogeneous preparation of the TatBC complex.

We found that the detergent GDN was able to solubilize TatBC from E. coli membranes as a single $\sim 440 \mathrm{kDa}$ complex as judged by BN-PAGE (Figure 1A). This complex is similar in size to the TatBC complex released from the membrane by digitonin (Figure 1A). ${ }^{28}$ Some minor fragmentation of the TatBC complex is typically observed upon digitonin solubilization ${ }^{28}$ (Figure 1A). However, no fragmentation of the complex was seen following GDN extraction (Figure 1A).

We purified the GDN-solubilized TatBC complex using a hexahistidine tag on the TatC protein. The purified TatBC complex was homogeneous as judged by BN-PAGE and by the shape of the elution profile on size-exclusion chromatography (Figure 1B-D). 
A

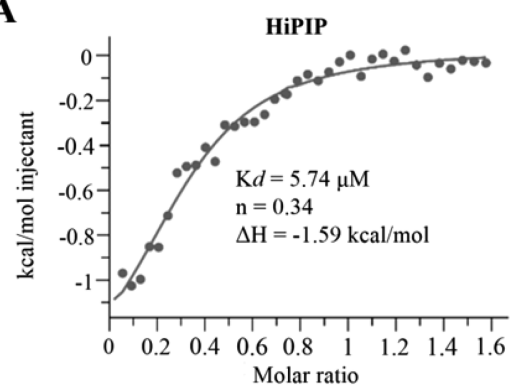

B

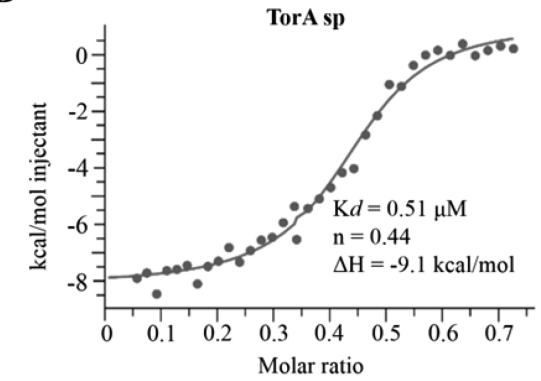

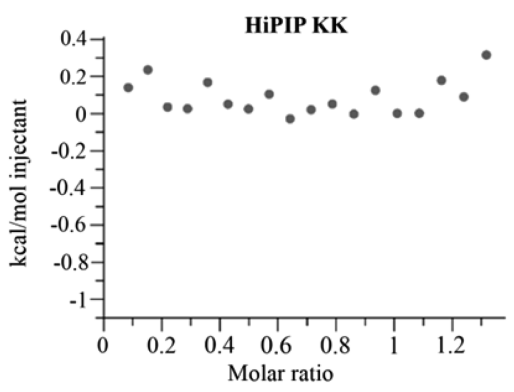

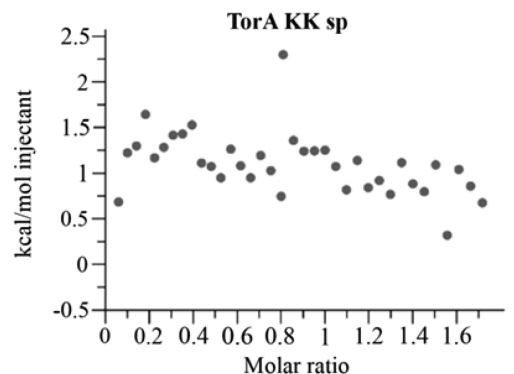

Figure 3. GDN-solubilized TatBC interacts with Tat precursors with low micromolar affinity. ITC titrations of TatBC-His ${ }_{6}$ with (A) the A.ferrooxidans HiPIP precursor or (B) the signal peptide of E. coli TorA (TorA sp). TatBC- $\mathrm{His}_{6}$ was present in the cell at a concentration of $45 \mu \mathrm{M}$. The titrant was 150 $\mu \mathrm{M}$ HiPIP or $85 \mu \mathrm{M}$ TorA sp. In each case, the left-hand column shows a titration using the wild-type precursor protein or peptide and the right-hand column a titration using a variant in which the signal peptide twin arginine motif has been replaced with twin lysine residues. The molar ratio corresponds to the ratio of titrant molecules to $\mathrm{TatC}-\mathrm{His}_{6}$ proteins present. Fitting was performed using the one-site model in Origin software (Malvern Instruments).

The GDN-purified TatBC complex was subjected to quantitative lipidomics mass spectrometry. This analysis identified 129 (SD of 8) molecules of phosphatidylethanolamine (PE), 1.50 (SD of 0.04) molecules of phosphatidylglycerol (PG), and 0.36 (SD of 0.02 ) molecule of cardiolipin (CL) per TatC polypeptide (based on three technical repeats). This equates to a relative phospholipid abundance of $98.6 \%$ PE, $1.1 \%$ PG, and $0.3 \% \mathrm{CL}$. For comparison, the relative abundances of the different classes of phospholipids in E. coli are typically in the ranges $70-80 \% \mathrm{PE}, 15-25 \% \mathrm{PG}$, and $5-10 \% \mathrm{CL} .{ }^{51}$ Thus, the acidic phospholipids PG and CL are under-represented in the phospholipid annulus that co-purifies with the TatBC complex relative to the bulk membrane phospholipid composition.

GDN-Solubilized TatBC Complexes Can Bind to Precursor Proteins. To determine whether the TatBC complex remains functional following solubilization with GDN, we assessed the ability of the solubilized complex to bind Tat precursor proteins. The native E. coli precursor proteins used in these experiments were the putative $\mathrm{Cu}(\mathrm{I})$ oxidase $\mathrm{CueO}^{52}$ and the enzyme MdoD involved in osmoregulated periplasmic glucan synthesis. ${ }^{53} \mathrm{We}$ also employed the high-potential iron-sulfur protein (HiPIP) from Acidithiobacillus ferrooxidans, which is a heterologous substrate of the E. coli Tat system. ${ }^{17,54}$

Membranes from strains expressing TatBC were solubilized in GDN and the soluble extract mixed with the signal peptidebearing precursor protein of interest. Formation of the complex between the precursor protein and TatBC was assessed by copurification using a hexahistidine tag on the C-terminus of the precursor protein. GDN-solubilized TatBC bound to all three test precursor proteins (Figure 2A, left). However, little or no binding was observed when the twin arginine motif in the precursor signal peptides was replaced with twin lysine residues, a substitution that is known to interfere with binding of the precursor to the TatBC complex. ${ }^{10,11}$ Precursor binding by
GDN-solubilized TatBC was benchmarked against the precursor binding behavior of the TatBC complex solubilized in digitonin (Figure 2A, right). Identical patterns of complex formation were observed for the two detergents.

The precursor binding specificity of the GDN-solubilized TatBC complex was unaltered if the precursor proteins were allowed to associate with TatBC in membranes before, rather than after, GDN solubilization (Figure 2B).

Taken together, these experiments show that the TatBC complex solubilized in GDN retains the precursor binding specificity of the native Tat system.

Biophysical Analysis of TatBC-Precursor Interactions. The availability of a homogeneous preparation of the TatBC complex in a detergent other than digitonin allowed us to undertake biophysical analysis of TatBC-precursor interactions.

Isothermal titration calorimetry (ITC) was used to investigate the thermodynamics of the interaction between the TatBC complex and precursor proteins. In performing these experiments, we faced the technical challenge that both of these binding partners need to be soluble at a high concentration to compensate for the limited sensitivity of the technique. The GDN-solubilized TatBC complex could be concentrated to an appropriate level, but A. ferroxidans HiPIP was the only one of the available precursor proteins with the solubility necessary to act as the titrated ligand.

Titration of HiPIP into TatBC resulted in a relatively weak calorimetric signal (Figure 3A, left). However, when the experiment was repeated using the binding-defective twin lysine-substituted variant of HiPIP, only heats of dilution were seen (Figure 3A, right). This indicates that the signal observed with the wild-type HiPIP protein represents a specific and physiologically appropriate interaction with the TatBC complex. The calorimetric data could be fitted with a $K_{\mathrm{d}}$ of $\sim 6 \mu \mathrm{M}$ and a 
binding stoichiometry of approximately one HiPIP molecule for every three TatC molecules.

We repeated the ITC experiments using a synthetic peptide corresponding to the signal peptide of the E. coli Tat substrate TorA (Figure 3B). Unambiguous binding of the signal peptide to TatBC was observed. This binding was abolished by a twin lysine for twin arginine substitution in the signal peptide twin arginine motif, as expected of an authentic Tat targeting interaction. The TatBC complex bound the TorA signal peptide $\sim 10$-fold more tightly $\left(K_{\mathrm{d}} \sim 0.5 \mu \mathrm{M}\right)$ than it did the full-length HiPIP precursor protein. Binding of the TorA signal peptide to the TatBC complex was again substoichiometric with TatC ( 0.44 peptide bound per TatC).

The kinetics of binding of the precursor to TatBC were probed using surface plasmon resonance (SPR). GDN-solubilized TatBC was immobilized on the sensor chip using TatB antibodies. The interactions of TatBC with the A. ferroxidans HiPIP precursor could not be studied by this assay as HiPIP was found to have nonspecific interactions with the antibody-coated chip. By contrast, the E. coli $\mathrm{CueO}$ precursor exhibited interactions only when TatBC was present. Injection of the wild-type $\mathrm{CueO}$ precursor produced sensorgrams typical of very slow binding kinetics (Figure 4A). Using a 1:1 binding model, the $k_{\mathrm{ON}}$ was estimated to be approximately $400 \pm 70 \mathrm{M}^{-1} \mathrm{~s}^{-1}(n=2)$ and the $k_{\mathrm{OFF}} 0.0018 \pm 0.0007 \mathrm{~s}^{-1}(n=2)$. On the basis of these kinetic parameters, the calculated $K_{\mathrm{d}}$ between the two partners is
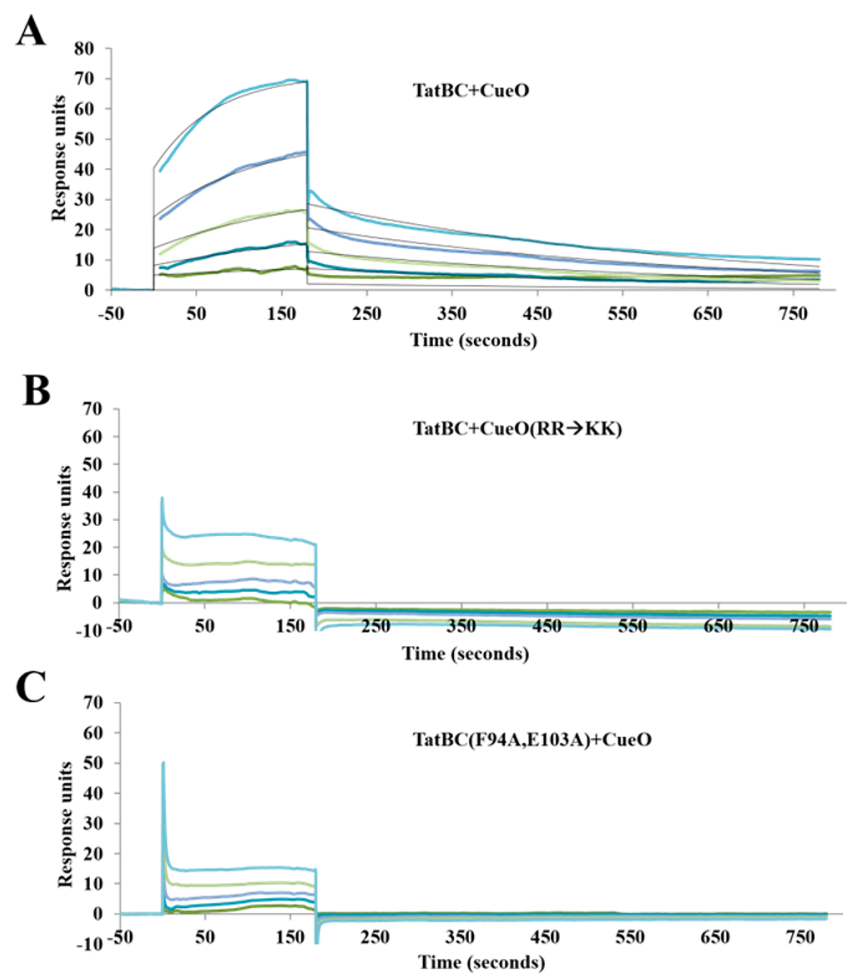

Figure 4. Tat-targeted precursor proteins exhibit slow binding and dissociation kinetics with the TatBC complex. SPR sensorgrams depict the signal obtained upon injection of either (A and C) the wild-type $\mathrm{CueO}$ precursor or (B) a $\mathrm{CueO}$ variant in which the twin arginine residues of the Tat motif have been replaced with twin lysine residues. The injected precursor protein concentrations are 1.9, 3.8, 7.5, 15, and $30 \mu \mathrm{M}$. The chip was coated with either (A and B) TatBC-strepII- $\mathrm{His}_{6}$ or $(C)$ a precursor binding-deficient $\mathrm{Tat} B C-\mathrm{His}_{6}$ variant containing the TatC substitutions F94A and E103A. The sensorgrams in panel A were fitted using a 1:1 binding model (black lines).
4.5 $\mu \mathrm{M}$. Equilibrium binding analysis could not be used to determine a more reliable $K_{\mathrm{d}}$ for the interaction because saturation was not reached within a realistic analyte injection time. Additionally, the bulk contribution to the measured signals was significant, possibly because of the presence of detergent micelles. Sensorgrams for the $\mathrm{CueO}$ precursor variant with a twin lysine for twin arginine substitution in the signal peptide showed only transient background binding to the surface (Figure 4B). Similarly, only background binding was observed when wild-type CueO was injected into a flow cell coated with a TatBC variant containing two substitutions (F94A and E103A) that abolish precursor binding ${ }^{17}$ (Figure $4 \mathrm{C}$ ). Thus, the binding interaction observed between the wild-type TatBC and $\mathrm{CueO}$ proteins exhibits the specificity expected of an authentic Tat precursorTatBC interaction.

\section{DISCUSSION}

The only established method for purifying the E. coli TatBC complex in a homogeneous state uses the detergent digitonin to solubilize the complex. We show here that a homogeneous preparation of the TatBC complex can also be produced using the detergent GDN. Digitonin is a steroidal saponin natural product isolated from the plant Digitalis purpurea. GDN is a semisynthetic saponin that structurally resembles digitonin in combining a hydrophobic steroidal group with a hydrophilic dimaltose group. ${ }^{38}$ Plausibly, it is this structural similarity between the two detergents that allows them to extract the TatBC complex from the membrane without fragmentation. The fragility of the TatBC complex has been ascribed to weak, and possibly dynamic, interactions between TatC subunits. ${ }^{1,14}$ Our lipidomics analysis of the GDN-purified TatBC complex indicates that substantial quantities of phospholipids are copurified with the protein ( $>100$ phospholipid molecules per TatC subunit). This phospholipid:protein ratio is high by comparison with membrane proteins purified in conventional detergents (e.g., ref 55), suggesting that GDN may be able to preserve an extensive lipid belt around the protein or allow the formation of a bicelle-like structure. The large number of copurifying phospholipids may play a part in stabilizing the TatBC complex upon GDN solubilization. The proportion of phospholipids with acidic headgroups that co-purifies with the TatBC complex is far lower than their abundance in E. coli membranes. This suggests a degree of specificity in the way the TatBC complex interacts with membrane phospholipids (though selective extraction by GDN is also a possibility). In this context, it is notable that previous studies have shown that Tat transport in $E$. coli is sensitive to the membrane phospholipid composition. ${ }^{56,57}$ Indeed, a recent study showed that Tat activity requires specifically PE, but not PG or CL. ${ }^{58}$ It may, therefore, be functionally relevant that the phospholipids that are co-purified with the TatBC complex are enriched with PE relative to the bulk membrane phospholipid composition.

The GDN-solubilized TatBC preparation has allowed us to quantitatively characterize TatBC-precursor interactions in a fully defined system. For technical reasons, it has not been possible to systematically obtain both thermodynamic and kinetic data for a single type of precursor protein. Instead, we have obtained representative data for a range of precursor proteins and signal peptides. Some comparative data are available for interactions of the precursor with the Tat system in vesicular membrane systems, though it is important to note that many experiments using the thylakoid Tat system have relied on the 
use of engineered precursors with artificially enhanced binding affinities.

Our ITC data indicate that signal peptides and full-length precursor proteins both have low micromolar binding affinities for the TatBC complex $\left(K_{\mathrm{d}}\right.$ values of $\sim 0.5 \mu \mathrm{M}$ for the TorA signal peptide and $\sim 6 \mu \mathrm{M}$ for the heterologous HiPIP precursor). For comparison, transport of the Tat substrate SufI into E. coli inner membrane vesicles (IMVs) was found to be competitively inhibited by the $\mathrm{CueO}$ precursor protein with a $K_{\mathrm{i}}$ of $\sim 0.1 \mu \mathrm{M},{ }^{29}$ while the $K_{\mathrm{d}}$ of IMVs for Sufl has been independently estimated from fluorescence resonance energy transfer experiments to be in the range of $7-23 \mathrm{nM} .^{35}$ Similarly, Allochromatium vinosum HiPIP can be inferred to competitively inhibit the transport of CueO precursors with a $K_{\mathrm{i}}$ of $<1 \mu \mathrm{M}^{59}$ Investigations using native substrates of the thylakoid Tat system have estimated a $K_{0.5}$ for transport of $77 \mathrm{nM}$ and showed competition with a $K_{\mathrm{i}}$ of either $46 \mathrm{nM}^{36}$ or $<250 \mathrm{nM} .^{37}$ Taken together these experiments suggest that translocase-precursor interactions are around an order of magnitude tighter in membrane systems than in a detergent solution. This raises the possibility that the binding interaction is modified by the native lipid environment beyond the shell of the phospholipid that is copurified with the TatBC complex.

We observed substoichiometric ratios of binding of the precursor to TatC in our ITC experiments ( 1 in 2 to 1 in 3 precursors per $\mathrm{Tat} C$ ), implying that not all $\mathrm{Tat} C$ binding sites are equivalent in our GDN-solubilized TatBC preparation. This could be a reflection of damage to the TatBC complexes during purification. However, our observations would also be consistent with the possibility that the TatBC complex is functionally asymmetric, with different $\mathrm{Tat} C$ protomers within the complex having non-identical affinities for precursor proteins. Such a model has already been proposed on the basis of the observation that only one or two precursor molecules appear to be bound to each E. coli TatBC complex in low-resolution electron microscopy studies. ${ }^{29}$ Nevertheless, it should be noted that both native and artificial precursor proteins have been reported to interact with the E. coli and thylakoid Tat systems through at least two signal peptides on one substrate molecule. ${ }^{24,25}$ In addition, quantitative, transport-competent, binding of precursor proteins to TatC molecules has been measured in the thylakoid Tat system, ${ }^{60}$ albeit in experiments using a precursor with unphysiologically tight binding properties.

E. coli TatBC-precursor complexes formed in cells can survive solubilization and multistep purification, ${ }^{29}$ a phenomenon also evident in the co-purification experiments shown in Figure 2B. At first sight, these observations appear to be in conflict with the low micromolar to high nanomolar $K_{\mathrm{d}}$ values for these complexes we measure here. Our kinetic analysis confirms a relatively slow dissociation rate constant $\left(k_{\text {off }} \approx 0.0018 \pm 0.0007 \mathrm{~s}^{-1}\right)$ for the precursor-TatBC interaction. However, it is also evident that the rate of complex formation is unusually slow $\left(k_{\text {on }} \approx 400 \pm 70\right.$ $\mathrm{M}^{-1} \mathrm{~s}^{-1}$ ), which results in the unexpectedly weak binding affinity of the complex through the relationship $K_{\mathrm{d}}=k_{\text {off }} / k_{\text {on }}$.

The slow rate of release of the precursor protein from the TatBC complex in a detergent solution contrasts with the ready exchangeability of precursors bound to the Tat system in membranes $^{34}$ and the $>20$-fold faster dissociation constant $\left(k_{\text {off }}\right.$ $\left.\approx 0.042 \mathrm{~s}^{-1}\right)$ and approximately 10000 -fold increase in association rate constant $\left(k_{\mathrm{on}} \approx 10^{6}-10^{7} \mathrm{M}^{-1} \mathrm{~s}^{-1}\right)$ inferred for the Tat system in IMVs. ${ }^{35}$ A tentative conclusion from this comparison is that the phospholipid bilayer or other cellular components dramatically modulate the kinetics of interaction of the TatBC complex with precursor proteins. A possible interpretation is that a structural transition in the TatBC complex accompanies precursor binding and that the activation barrier for this transition is higher in a detergent solution.

In conclusion, this work has given a first quantitative insight into the precursor binding properties of the isolated TatBC receptor complex. Despite the multivalent nature of the TatBC complex, its ligand binding behavior can be satisfactorily modeled using a single type of binding site with monophasic association kinetics. This study provides a basis for probing the influence of other cellular components on the precursor binding properties of the TatBC complex and how precursor binding interactions may change during the Tat transport cycle. The novel GDN-dependent preparation of the TatBC complex reported here should prove to be widely useful in structurefunction studies of the Tat system.

\section{ASSOCIATED CONTENT}

\section{S Supporting Information}

The Supporting Information is available free of charge on the ACS Publications website at DOI: 10.1021/acs.biochem.8b00026.

List of plasmids used (Table S1) and a list of mutagenic primers (Table S2) (PDF)

\section{AUTHOR INFORMATION}

\section{Corresponding Author}

*E-mail: ben.berks@bioch.ox.ac.uk. Phone: +44-1865-613294.

\section{ORCID $\odot$}

Joseph Gault: 0000-0001-7686-2983

Ben C. Berks: 0000-0001-9685-4067

\section{Present Addresses}

${ }^{\S}$ M.W.: Institute of Infection, Immunity and Inflammation, University Place, Glasgow G12 8TA, United Kingdom.

"S.C.Y.: Menara Sunway, 47500 Subang Jaya, Selangor, Malaysia.

\section{Author Contributions}

M.W. and B.C.B. conceived the work and wrote the manuscript. M.W. conducted all experiments and data analysis, with the exception of the phospholipid analysis, which was undertaken by J.G. and C.V.R. S.C.Y. constructed the $\mathrm{CueO}$ and $\mathrm{MdoD}$ expression plasmids. All authors have given approval to the final version of the manuscript.

\section{Funding}

This work was supported by the Medical Research Council through Grants MR/K000721/1 and MR/N020413/1 and the European Research Council through Grant ENABLE (641317). J.G. was supported by a Junior Research Fellowship at The Queen's College, Oxford. S.C.Y. was supported by a studentship from the University of Oxford and Pembroke College, Oxford. C.V.R. and B.C.B. are Wellcome Trust Investigators (award codes $104633 / \mathrm{Z} / 14 / \mathrm{Z}$ and $107929 / \mathrm{Z} / 15 / \mathrm{Z}$, respectively).

\section{Notes}

The authors declare no competing financial interest.

\section{ACKNOWLEDGMENTS}

The authors acknowledge access to the Biophysics Facility of the University of Oxford Department of Biochemistry. The authors thank Martin Krehenbrink for advice on Tat biochemistry and the analysis of protein-protein interactions, David Staunton for advice on biophysical methods, Frank Lennartz for advice on SPR data analysis, Peter Gimeson for assistance with ITC data 
processing, and Felicity Alcock and Tracy Palmer for comments on the manuscript.

\section{ABBREVIATIONS}

BN-PAGE, blue native polyacrylamide gel electrophoresis; CL, cardiolipin; GDN, glyco-diosgenin; HiPIP, high-potential ironsulfur protein; IMVs, inner membrane vesicles; ITC, isothermal titration calorimetry; PE, phosphatidylethanolamine; PG, phosphatidylglycerol; RP LC-MS, reverse phase liquid chromatography tandem mass spectrometry; SPR, surface plasmon resonance.

\section{REFERENCES}

(1) Berks, B. C. (2015) The twin-arginine protein translocation pathway. Annu. Rev. Biochem. 84, 843-864.

(2) Palmer, T., and Berks, B. C. (2012) The twin-arginine translocation (Tat) protein export pathway. Nat. Rev. Microbiol. 10, 483-496.

(3) Celedon, J. M., and Cline, K. (2013) Intra-plastid protein trafficking: how plant cells adapted prokaryotic mechanisms to the eukaryotic condition. Biochim. Biophys. Acta, Mol. Cell Res. 1833, 341351.

(4) Cline, K. (2015) Mechanistic Aspects of Folded Protein Transport by the Tat System. J. Biol. Chem. 290, 16530-16538.

(5) Carrie, C., Weissenberger, S., and Soll, J. (2016) Plant mitochondria contain the protein translocase subunits TatB and TatC. J. Cell Sci. 129, 3935-3947.

(6) Burger, G., Gray, M. W., Forget, L., and Lang, B. F. (2013) Strikingly bacteria-like and gene-rich mitochondrial genomes throughout jakobid protists. Genome Biol. Evol. 5, 418-438.

(7) Berks, B. C. (1996) A common export pathway for proteins binding complex redox cofactors? Mol. Microbiol. 22, 393-404.

(8) Chaddock, A. M., Mant, A., Karnauchov, I., Brink, S., Herrmann, R. G., Klosgen, R. B., and Robinson, C. (1995) A new type of signal peptide: central role of a twin-arginine motif in transfer signals for the $\Delta \mathrm{pH}$-dependent thylakoidal protein translocase. EMBO J. 14, 27152722.

(9) Cline, K., and Mori, H. (2001) Thylakoid $\Delta$ pH-dependent precursor proteins bind to a cpTatC-Hcflo6 complex before Tha4dependent transport. J. Cell Biol. 154, 719-729.

(10) Alami, M., Luke, I., Deitermann, S., Eisner, G., Koch, H. G., Brunner, J., and Muller, M. (2003) Differential interactions between a twin-arginine signal peptide and its translocase in Escherichia coli. Mol. Cell 12, 937-946.

(11) Rollauer, S. E., Tarry, M. J., Graham, J. E., Jaaskelainen, M., Jager, F., Johnson, S., Krehenbrink, M., Liu, S. M., Lukey, M. J., Marcoux, J., McDowell, M. A., Rodriguez, F., Roversi, P., Stansfeld, P. J., Robinson, C. V., Sansom, M. S., Palmer, T., Hogbom, M., Berks, B. C., and Lea, S. M. (2012) Structure of the TatC core of the twin-arginine protein transport system. Nature 492, 210-214.

(12) Holzapfel, E., Eisner, G., Alami, M., Barrett, C. M., Buchanan, G., Luke, I., Betton, J. M., Robinson, C., Palmer, T., Moser, M., and Muller, M. (2007) The entire N-terminal half of TatC is involved in twinarginine precursor binding. Biochemistry 46, 2892-2898.

(13) Ma, X., and Cline, K. (2013) Mapping the signal peptide binding and oligomer contact sites of the core subunit of the pea twin arginine protein translocase. Plant Cell 25, 999-1015.

(14) Alcock, F., Stansfeld, P. J., Basit, H., Habersetzer, J., Baker, M. A., Palmer, T., Wallace, M. I., and Berks, B. C. (2016) Assembling the Tat protein translocase. eLife 5, 5 .

(15) Huang, Q., Alcock, F., Kneuper, H., Deme, J. C., Rollauer, S. E., Lea, S. M., Berks, B. C., and Palmer, T. (2017) A signal sequence suppressor mutant that stabilizes an assembled state of the twin arginine translocase. Proc. Natl. Acad. Sci. U. S. A. 114, E1958-E1967.

(16) Dabney-Smith, C., Mori, H., and Cline, K. (2006) Oligomers of Tha4 organize at the thylakoid Tat translocase during protein transport. J. Biol. Chem. 281, 5476-5483.
(17) Alcock, F., Baker, M. A., Greene, N. P., Palmer, T., Wallace, M. I., and Berks, B. C. (2013) Live cell imaging shows reversible assembly of the TatA component of the twin-arginine protein transport system. Proc. Natl. Acad. Sci. U. S. A. 110, E3650-E3659.

(18) Rose, P., Frobel, J., Graumann, P. L., and Muller, M. (2013) Substrate-dependent assembly of the Tat translocase as observed in live Escherichia coli cells. PLoS One 8, e69488.

(19) Zhang, Y., Wang, L., Hu, Y., and Jin, C. (2014) Solution structure of the TatB component of the twin-arginine translocation system. Biochim. Biophys. Acta, Biomembr. 1838, 1881-1888.

(20) Ramasamy, S., Abrol, R., Suloway, C. J., and Clemons, W. M., Jr. (2013) The glove-like structure of the conserved membrane protein TatC provides insight into signal sequence recognition in twin-arginine translocation. Structure 21, 777-788.

(21) Blummel, A. S., Haag, L. A., Eimer, E., Muller, M., and Frobel, J. (2015) Initial assembly steps of a translocase for folded proteins. Nat. Commun. 6, 7234.

(22) Buchanan, G., de Leeuw, E., Stanley, N. R., Wexler, M., Berks, B. C., Sargent, F., and Palmer, T. (2002) Functional complexity of the twinarginine translocase TatC component revealed by site-directed mutagenesis. Mol. Microbiol. 43, 1457-1470.

(23) Cleon, F., Habersetzer, J., Alcock, F., Kneuper, H., Stansfeld, P. J., Basit, H., Wallace, M. I., Berks, B. C., and Palmer, T. (2015) The TatC component of the twin-arginine protein translocase functions as an obligate oligomer. Mol. Microbiol. 98, 111-129.

(24) Ma, X., and Cline, K. (2010) Multiple precursor proteins bind individual Tat receptor complexes and are collectively transported. ЕМВО J. 29, 1477-1488.

(25) James, M. J., Coulthurst, S. J., Palmer, T., and Sargent, F. (2013) Signal peptide etiquette during assembly of a complex respiratory enzyme. Mol. Microbiol. 90, 400-414.

(26) Bolhuis, A., Mathers, J. E., Thomas, J. D., Barrett, C. M., and Robinson, C. (2001) TatB and TatC form a functional and structural unit of the twin-arginine translocase from Escherichia coli. J. Biol. Chem. 276, 20213-20219.

(27) Oates, J., Barrett, C. M., Barnett, J. P., Byrne, K. G., Bolhuis, A., and Robinson, C. (2005) The Escherichia coli twin-arginine translocation apparatus incorporates a distinct form of TatABC complex, spectrum of modular TatA complexes and minor Tat $\mathrm{AB}$ complex. J. Mol. Biol. 346, 295-305.

(28) Orriss, G. L., Tarry, M. J., Ize, B., Sargent, F., Lea, S. M., Palmer, T., and Berks, B. C. (2007) TatBC, TatB, and TatC form structurally autonomous units within the twin arginine protein transport system of Escherichia coli. FEBS Lett. 581, 4091-4097.

(29) Tarry, M. J., Schafer, E., Chen, S., Buchanan, G., Greene, N. P., Lea, S. M., Palmer, T., Saibil, H. R., and Berks, B. C. (2009) Structural analysis of substrate binding by the TatBC component of the twinarginine protein transport system. Proc. Natl. Acad. Sci. U. S. A. 106, 13284-13289.

(30) Gerard, F., and Cline, K. (2007) The thylakoid proton gradient promotes an advanced stage of signal peptide binding deep within the Tat pathway receptor complex. J. Biol. Chem. 282, 5263-5272.

(31) Maurer, C., Panahandeh, S., Jungkamp, A. C., Moser, M., and Muller, M. (2010) TatB functions as an oligomeric binding site for folded Tat precursor proteins. Molecular biology of the cell 21, 41514161.

(32) Zoufaly, S., Frobel, J., Rose, P., Flecken, T., Maurer, C., Moser, M., and Muller, M. (2012) Mapping precursor-binding site on TatC subunit of twin arginine-specific protein translocase by site-specific photo crosslinking. J. Biol. Chem. 287, 13430-13441.

(33) Ulfig, A., Frobel, J., Lausberg, F., Blummel, A. S., Heide, A. K., Muller, M., and Freudl, R. (2017) The h-region of twin arginine signal peptides supports productive binding of bacterial Tat precursor proteins to the TatBC receptor complex. J. Biol. Chem. 292, 10865-10882.

(34) Bageshwar, U. K., Whitaker, N., Liang, F. C., and Musser, S. M. (2009) Interconvertibility of lipid- and translocon-bound forms of the bacterial Tat precursor pre-SufI. Mol. Microbiol. 74, 209-226. 
(35) Whitaker, N., Bageshwar, U. K., and Musser, S. M. (2012) Kinetics of precursor interactions with the bacterial Tat translocase detected by real-time FRET. J. Biol. Chem. 287, 11252-11260.

(36) Alder, N. N., and Theg, S. M. (2003) Protein transport via the cpTat pathway displays cooperativity and is stimulated by transportincompetent substrate. FEBS Lett. 540, 96-100.

(37) Ma, X., and Cline, K. (2000) Precursors bind to specific sites on thylakoid membranes prior to transport on the $\Delta \mathrm{pH}$ protein translocation system. J. Biol. Chem. 275, 10016-10022.

(38) Chae, P. S., Rasmussen, S. G., Rana, R. R., Gotfryd, K., Kruse, A. C., Manglik, A., Cho, K. H., Nurva, S., Gether, U., Guan, L., Loland, C. J., Byrne, B., Kobilka, B. K., and Gellman, S. H. (2012) A new class of amphiphiles bearing rigid hydrophobic groups for solubilization and stabilization of membrane proteins. Chem. - Eur. J. 18, 9485-9490.

(39) McDevitt, C. A., Hicks, M. G., Palmer, T., and Berks, B. C. (2005) Characterisation of Tat protein transport complexes carrying inactivating mutations. Biochem. Biophys. Res. Commun. 329, 693-698.

(40) Cline, K., and McCaffery, M. (2007) Evidence for a dynamic and transient pathway through the TAT protein transport machinery. EMBO J. 26, 3039-3049.

(41) Wexler, M., Sargent, F., Jack, R. L., Stanley, N. R., Bogsch, E. G., Robinson, C., Berks, B. C., and Palmer, T. (2000) TatD is a cytoplasmic protein with DNase activity. No requirement for TatD family proteins in Sec-independent protein export. J. Biol. Chem. 275, 16717-16722.

(42) Sambrook, J., and Russell, D. W. (2001) Molecular cloning: A laboratory manual, 3rd ed., Cold Spring Harbor Laboratory Press, Plainview, NY.

(43) Tartof, K. D., and H, C. A. (1987) Focus 9, 12.

(44) Gasteiger, E., Hoogland, C., Gattiker, A., Duvaud, S., Wilkins, M. R., Appel, R. D., and Bairoch, A. (2005) Protein Identification and Analysis Tools on the ExPASy Server. In The Proteomics Protocols Handbook (Walker, J. M., Ed.) pp 571-607, Humana Press, Totowa, NJ.

(45) King, J., and Laemmli, U. K. (1971) Polypeptides of the tail fibres of bacteriophage T4. J. Mol. Biol. 62, 465-477.

(46) Bligh, E. G., and Dyer, W. J. (1959) A rapid method of total lipid extraction and purification. Can. J. Biochem. Physiol. 37, 911-917.

(47) Bird, S. S., Marur, V. R., Sniatynski, M. J., Greenberg, H. K., and Kristal, B. S. (2011) Lipidomics profiling by high-resolution LC-MS and high-energy collisional dissociation fragmentation: focus on characterization of mitochondrial cardiolipins and monolysocardiolipins. Anal. Chem. 83, 940-949.

(48) Fahy, E., Sud, M., Cotter, D., and Subramaniam, S. (2007) LIPID MAPS online tools for lipid research. Nucleic Acids Res. 35, W606-612.

(49) Hatzixanthis, K., Clarke, T. A., Oubrie, A., Richardson, D. J., Turner, R. J., and Sargent, F. (2005) Signal peptide-chaperone interactions on the twin-arginine protein transport pathway. Proc. Natl. Acad. Sci. U. S. A. 102, 8460-8465.

(50) Scopes, R. K. (1974) Measurement of protein by spectrophotometry at $205 \mathrm{~nm}$. Anal. Biochem. 59, 277-282.

(51) Kadner, R. J. (1996) Cytoplasmic membrane. In Escherichia coli and Salmonella: Cellular and Molecular Biology (Neidhardt, F. C., Ed.) pp 58-87, American Society for Microbiology Press, Washington, DC.

(52) Singh, S. K., Grass, G., Rensing, C., and Montfort, W. R. (2004) Cuprous oxidase activity of $\mathrm{CueO}$ from Escherichia coli. Journal of bacteriology 186, 7815-7817.

(53) Lequette, Y., Odberg-Ferragut, C., Bohin, J. P., and Lacroix, J. M. (2004) Identification of $m d o D$, an $m d o G$ paralog which encodes a twinarginine-dependent periplasmic protein that controls osmoregulated periplasmic glucan backbone structures. Journal of bacteriology 186, 3695-3702.

(54) Bruscella, P., Cassagnaud, L., Ratouchniak, J., Brasseur, G., Lojou, E., Amils, R., and Bonnefoy, V. (2005) The HiPIP from the acidophilic Acidithiobacillus ferrooxidans is correctly processed and translocated in Escherichia coli, in spite of the periplasm $\mathrm{pH}$ difference between these two micro-organisms. Microbiology 151, 1421-1431.

(55) Bechara, C., Noll, A., Morgner, N., Degiacomi, M. T., Tampe, R., and Robinson, C. V. (2015) A subset of annular lipids is linked to the flippase activity of an ABC transporter. Nat. Chem. 7, 255-262.
(56) Mikhaleva, N. I., Santini, C. L., Giordano, G., Nesmeyanova, M. A., and Wu, L. F. (1999) Requirement for phospholipids of the translocation of the trimethylamine $\mathrm{N}$-oxide reductase through the Tat pathway in Escherichia coli. FEBS Lett. 463, 331-335.

(57) Sikdar, R., and Doerrler, W. T. (2010) Inefficient Tat-dependent export of periplasmic amidases in an Escherichia coli strain with mutations in two DedA family genes. Journal of bacteriology 192, 807818.

(58) Rathmann, C., Schlosser, A. S., Schiller, J., Bogdanov, M., and Bruser, T. (2017) Tat transport in Escherichia coli requires zwitterionic phosphatidylethanolamine but no specific negatively charged phospholipid. FEBS Lett. 591, 2848-2858.

(59) Stolle, P., Hou, B., and Bruser, T. (2016) The Tat substrate CueO is transported in an incomplete folding state. J. Biol. Chem. 291, 1352013528.

(60) Celedon, J. M., and Cline, K. (2012) Stoichiometry for binding and transport by the twin arginine translocation system. J. Cell Biol. 197, $523-534$. 